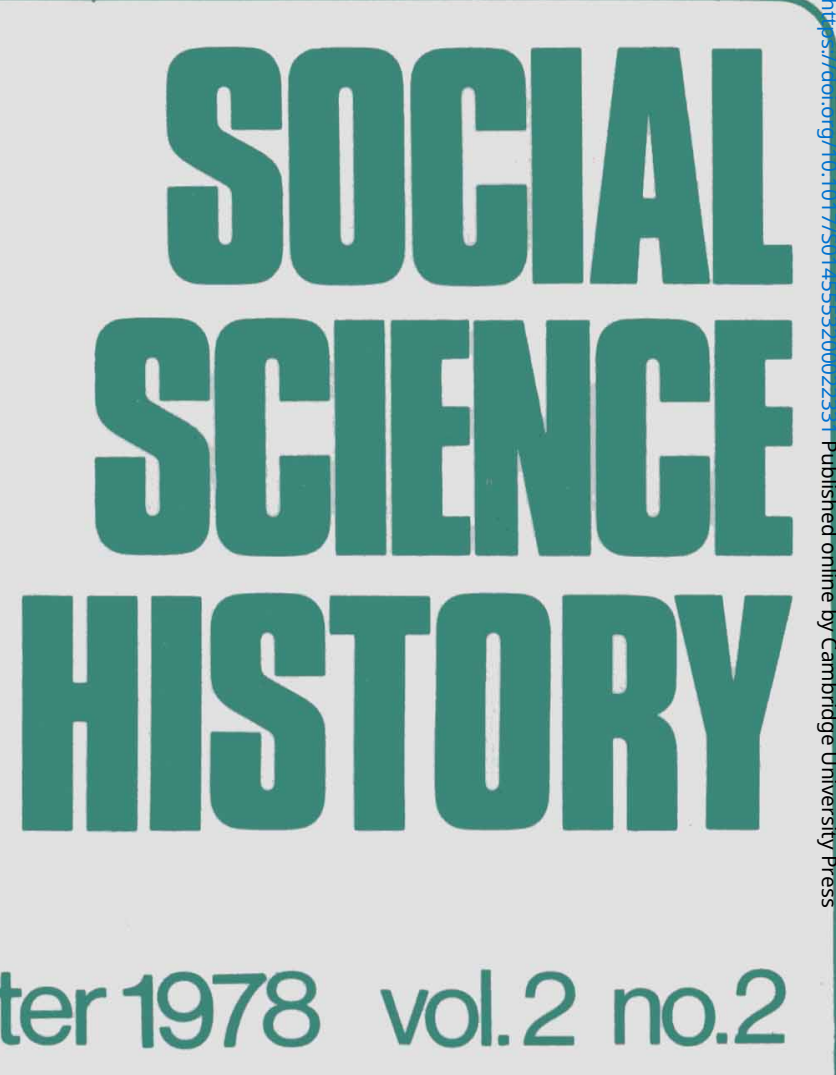

The Official Journal of the Social Science History Association

published by:

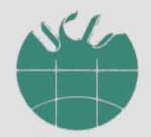

University Center for International Studies University of Pittsburgh 


\section{ASSOCIATION OFFICERS}

PRESIDENT

Allan G. Bogue

University of Wisconsin
VICE PR ESIDENT

Warren Miller

University of Michigan
EXECUTIVE DIRECTOR

Jerome M. Clubb

University of Michigan

\section{MANAGING EDITORS}

James Q. Graham, Jr.

Bowling Green State University
Robert P. Swierenga

Kent State University

\section{ASSOCIATE EDITORS}

William O. Aydelotte

University of Iowa

Thomas B. Alexander University of MissouriColumbia

Howard W. Allen

Southern Illinois University

Robert F. Berkhofer, Jr. University of Michigan

Walter Dean Burnham

Massachusetts Institute of Technology

Rondo Cameron

Emory University

Thomas F. Carney

University of Manitoba, Canada

Aage R. Clausen

Ohio State University

Thomas C. Cochran

University of Pennsyluania

Philip D. Curtin

Johns Hopkins University

\author{
Lee Benson \\ University of \\ Pennsylvania
}

Warren Miller

University of

Michigan

\section{BOARD OF EDITORS}

(2)

Robert W. Fogel

Harvard University

Hildred Geertz

Princeton University

Clyde Griffen

Vassar College

John Hall

Yale University

Samuel P. Hays

University of Pittsburgh

Barbara Laslett

University of Southern

California, Los Angeles

Donald R. Matthews

University of Washington

Birgitta Oden

University of Lund, Sweden

Stein Rokkan

Michaelsen Institute, Norway

Gilbert Rozman

Princeton University
Peggy R. Sanday

University of Pennsylvanio

G. William Skinner

Stanford University

Daniel Scott Smith

University of Illinois, Chicago Circle

John J. TePaske

Duke University

Charles Tilly

University of Michigan

Paul Uselding

University of Illinois, Urbana-Champaign

Etienne van de Walle University of Pennsylvania

David Ward

University of Wisconsin

E. A. Wrigley

Cambridge Group for the History of Population and Social Structure
ASSISTANT EDITOR

Rachael Rockwell Graham
ASSOCIATION NEWS EDITOR

Marianne Carlson-Hartwell

EDITORIAL ASSISTANTS

Sue Hay ward William T. Forsberg Lori Rider

Social Science History is published quarterly for the Social Science History Association by UCIS Publications, University of Pittsburgh. Social Science History is sent to all members of the Association and to institutions holding subscriptions. Membership rates are: students, \$8.00; faculty, \$15.00; charter membership, \$100.00; library subscriptions, \$20.00. Student, faculty, and library subscriptions are for the volume year; charter membership is for three volume years. Because subscriptions are by volume year, an individual joining during the year will receive the back issues plus the remaining issues of the current volume. Membership applications and reprint correspondence should be addressed to Jerome M. Clubb, Center for Political Studies, Box 1248 , University of Michigan, Ann Arbor, MI 48106. Inquiries concerning institutional subscriptions, single copies, and back issues should be sent to UCIS Publications, University Center for International Studies, G-6 Mervis Hall, University of Pittsburgh, Pittsburgh, PA 15260. All contributions must be typed double-space (including footnotes and quotations) and submitted in three copies to J. Q. Graham, Department of History, Bowling Green State University, Bowling Green, OH 43403. Footnotes and tables should appear separately at the end of the manuscript. Format should follow the Chicago Manual of Style: for spelling and punctuation, prospective contributors should consult Webster's Third New International Dictionary. A style sheet may be obtained from the Editors. The Social Science History Association does not accept responsibility for statements of fact or opinion made by contributors. 


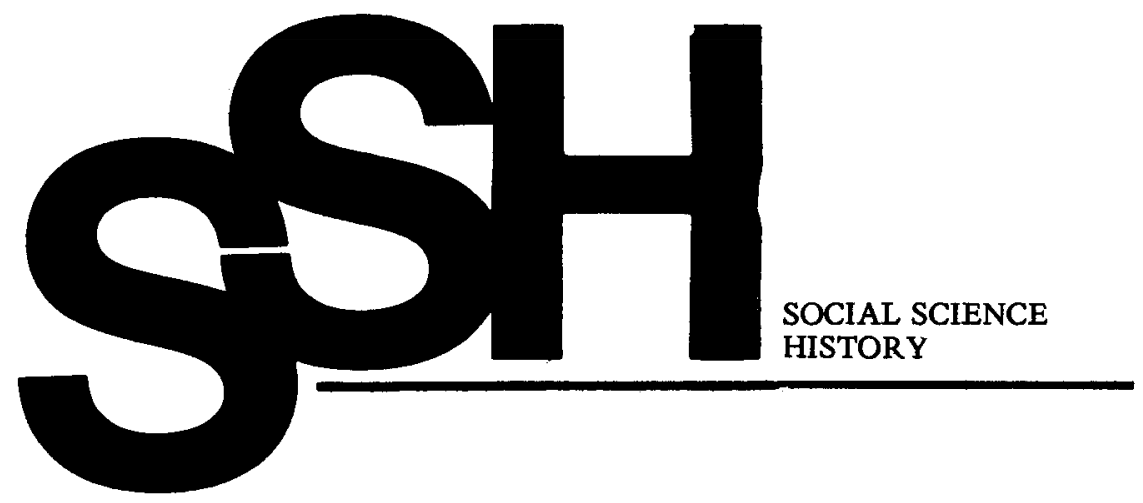

VOL. 2, NUMBER 2

WINTER, 1978

\section{TABLE OF CONTENTS}

New Sources for Social and Demographic History:

The Belgian Population Registers . . . . . . . . . . . . . . . . . 121 Myron P. Gutmann and Etienne van de Walle

Systems Analysis and Partisan Realignment . . . . . . . . . . . . . 144 John E. Chubb

Ecological Regression Verses Homogeneous Units:

A Specification Analysis . . . . . . . . . . . . . . . 172

Allan J. Lichtman and Laura Irwin Langbein

Professor Fessen on the "Egalitarian Myth" . . . . . . . . . . . . . . . . .194 Robert E. Gallman

Population Persistence and Early Industrialization in a Canadian City:

Hamilton, Ontario, 1851-1871 . . . . . . . . . . . . . .208

Michael B. Katz, Michael J. Doucet, and Mark J. Stern

An Historical Event and Its Interpretation: The Castilian

Grain Crisis of 1506-1507 . . . . . . . . . . . . . 230

Charles Gibson

Association News $\ldots \ldots \ldots \ldots \ldots \ldots \ldots \ldots \ldots \ldots \ldots$ 